\title{
生体機能細胞不死化技術亡 その生体機能再構成への利用
}

\section{特集 細胞治療と DDS}

\section{帯刀益夫*1)，矢内信昭 ${ }^{* 2)}$}

Possible applications of conditionally immortalized tissue cell lines with differentiation functions

If all distinct cell types of the body could be clonally isolated and stocked, similar to cDNA or genomic DNA libraries, they would be very invaluable for studying the tissue and cellular functions. We developed new method to establish conditionally immortalized cell lines that retain the differentiated cell functions similar to the original tissues, using the temperature-sensitive simian virus 40 large tumor antigen gene transgenic mouse. We successfully established many functional cell lines including hepatocyte, renal tubule cell, vascular smooth muscle cell, gastric surface mucous cell and various bone marrow stromal cells. We developed in vitro hematopoietic microenvironment to support growth and differentiation of hematopoietic stem cells and their progenitors by coculture with bone marrow stromal cells. In addition, we showed that bone marrow stromal cell lines have properties of mesenchymal stem cells that differentiate towards osteoblast, skeletal muscle cell, endothelial cell, adipocyte, smooth muscle cell and cardiomyocyte.

Using newly developed transgenic rat, we established various endothelial cell lines from brain capillary, retinal capillary, bone marrow, and choroid plexus, which can be used for a novel in vitro system to investigate transport functions at the blood-tissue fluid barrier and to develop high throughput screening systems.

Our transgenic mouse and rat will be useful to develop new types of cell lines with differentiation potentials. The established cell lines will be useful to study tissue functions at cellular and molecular levels and may be applicable to high throughput drug screening, toxicity test, and to develop the alternatives to animal experiments.

生体の組織を構成している分化機能を持つ紐胞は 200 種を超えると思われる. これら多様な細胞機 能を解明し, 生体組織の機能特性を再構築するためには, 個々の分化機能を保持した細胞を不死化す ることが必要となる。筆者らは, 温度感受性 SV 40 T-抗原遺层子導入トランスジェニックマウス，お よびラットを作出し, 多様な組織から分化機能を保持した不死化細胞株を樹立する方法を確立した。 筆者らは, 造血幹紐胞を支持する骨能有の間質細胞株を多数不死化し, 骨娟造血微小㻴境の in vitro 再 構成を目指した研究を進め, これら間質細胞株が, 紐胞間相互作用により培算系で造血細胞の特異的 支持機能を示すとともに, 骨芽細胞, 内皮細胞, 筋細胞, 脂肪細胞, 平滑筋紐胞など多䇐に分化でき る間葉系幹細胞としての性質も持っていることを明らかにした。

これら不死化した機能紐胞株は, 今後, 再生医学的研究とともに, 医楽品スクリーニングシステム や毒性評価システムの構築，新規生理活性物質の探索などへの創薬研究への利用も期待できる.

Masuo Obinata ${ }^{* 1}$, Nobuaki Yanai*2

key words : SV40 T-antigen, transgenic mouse, immortalized cell line, tissue function, stem cell

多細胞生物の体を構成している細胞のほとんどは 分化した細胞であり,これら分化した細胞は, 個体 発生の過程で一つの受精卵からの増殖と分化を経て

-1) Department of Cell Biology Institute of Development, Aging and Cancer, Tohoku University 東北大学加都医学研究所分子 発生研究分野

*2) Faculty of Nutrition Sciences, Miyagi-Gakuin Female University 宮城学院女子大学栄䖭科学科
産み出され, いろいろな組織を構築して機能を発揮 する. Sulston らはC. elegansを用いて, このよう な個体発生の過程が,一つの受精卵からはじまる細 胞分裂の時間的・空間的な過程としての細胞系譜と

して明確に示した. C. elegansは1個体が約 1,000 個の細胞で構成されており，このような解析が可能 であったが，ヒトをはじめとする哺乳動物において 


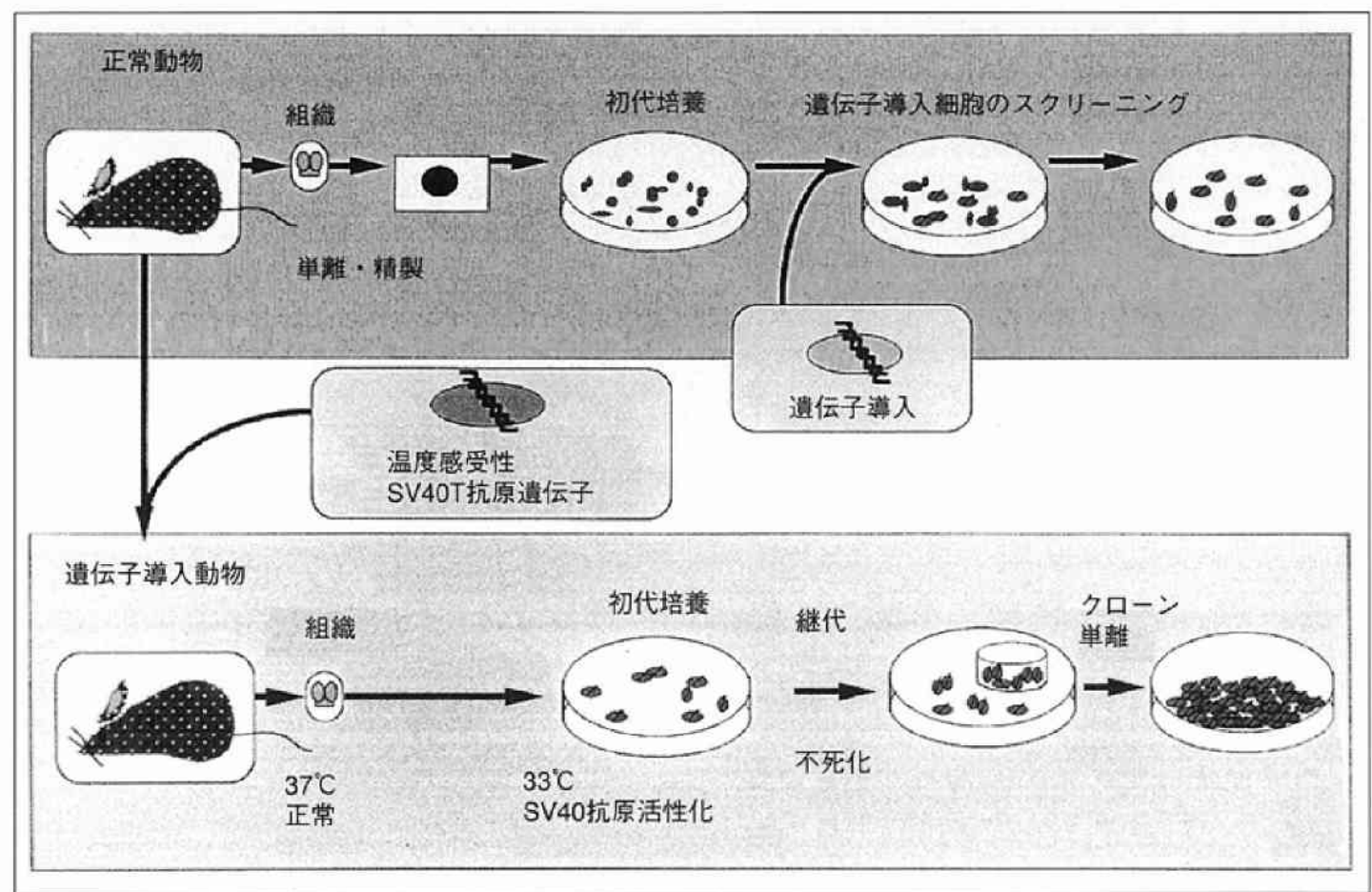

図 1

も，こうした細胞系譜とその結果としての分化した 細胞の特定化とその機能解析が必要であるが, ヒト の身体はおよそ 60 兆個に及ぶ細胞の集合であり, 分 化した細胞の種類も数百を超え, 複雑すぎて C. elegans と同様の解析は不可能である.しかし,もし 生体を構成する組織のすべての分化した細胞を細胞 株クローンライブラリーとして確保し，その特性を 明らかにし，これらを用いて生体組織の再構成を行 うことができれば, C. elegansで行われたと同様の 系統的な生体組織機能の研究が可能となる.

現在の組織培養法により生体の各組織の細胞を取 り出し培盖すると，一定期間増殖してから全体的な 細胞死(クライシス)を起こしつつ, 残った一部の細 胞から不死化する細胞が一定頻度で現れるが，これ らの細胞はいくつかの遺后子変異を起こし, 生体で の本来の分化機能を失っている場合が多い. 筆者ら は, 癌遺伝子の機能の研究から細胞の増殖と分化の 転換を癌遺伝子が調節することを示したが，これを 利用すれば，分化機能を保持した細胞株を樹立する ことが可能ではないかと考え，不死化のための遺伝 子として SV40 T-抗原を選び, トランスジェニック マウスを作出した1).
これまでSV40 T-抗原などのウイルス由来の癌 遗伝子を導入し，初代培養系で細胞を不死化しょう とする試みが多数成功しているが, これら遺伝子導 入は増殖性の細胞にのみ起こること, また個々の細 胞で染色体導入位置の相違があるなどの欠点があ り，トランスジェニックマウスを作出すればこのよ うな欠点を解決でき, 遺伝的にも同一の背景を持つ 細胞株を樹立できると考えた(図 1).特に, SV40 T抗原遗伝子の温度感受性変異株を導入したトランス ジェニックマウスを作出すれば, 温度依存的に増殖 と分化のスイッチが起きることも期待できる. 温度 感受性 T-抗原遺伝子はそれ自身のプロモーターを 用いているので, 多くの組織でユピキタスな発現が あり, 効率よくいろいろな組織の細胞の初代培養か ら分化機能を持つ細胞の株化が可能であることがわ かった.たとえば，アルブミンやチトクローム p 450 などの発現が認められる肝実質細胞株(TLR 1-4 株) 1), パソプレッシン応答能を持つ腎尿細管の細胞 株(TKC 細胞株) ${ }^{2)}$, 胃粘膜上皮細胞株(GSM 細胞 株) 3)などが樹立された。

これら樹立された細胞株はほとんどが温度依存性 の増殖を示すことがわかったが, 細胞系により, 当 
初の予想に反して, T-抗原が活性状態にある $33^{\circ} \mathrm{C}$ でも，すでに分化機能を発揮しており，T-抗原が失 活する $39^{\circ} \mathrm{C}$ の培養条件でも, 分化形質の増強や誘導 が認められない場合 (肝細胞, 腎尿細管細胞など) と, 胃粘膜細胞，血管平滑筋細胞，骨䯣ストローマ細胞 などのように飽和密度に達して増殖抑制がかかった ときあるいは $39^{\circ} \mathrm{C} に$ 移したとき分化形質の上昇が 認められる場合とがあった。この差は，T-抗原の制 御機能の細胞による差なのかもしれない. また, T抗原は癌抑制遺伝子産物 Rb, p 53 蛋白と結合する が，細胞系によってどちらと結合しているかが違っ ている可能性も考えられる，肝細胞，腎尿細管細胞

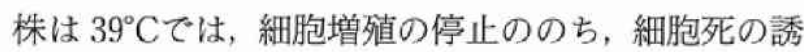
導が起き，この細胞死はアポトーシスであることが わかった。このアポトーシスの誘導は, $33^{\circ} \mathrm{Cでは}$ p 53 蛋白 (正常タイプ)が $\mathrm{T}$-抗原蛋白と複合体を形 成しているが, $39^{\circ} \mathrm{C} に$ 移ると T一抗原が消失し, 一過 的に p 53 蛋白が蓄積することによるものと思われ $3^{4,11)}$.

このようにして樹立された生体機能保持細胞株 は，論文として公表したものを表 1 にまとめている ので，興味のある方は論文をご覧いただきたい。こ れら細胞株については，それぞれの分化形質につい ての解析などが進められており, 本特集でもいくつ かの例が示されているが，ここでは，こうした機能 細胞株を用いて生体組織の in vitro での機能的再構 成を試みている筆者らの研究について述べる.

\section{不死化間質細胞株による骨髄造血微小環境の 培養系での再構成}

筆者らは，造血組織である骨髄に注目して，骨䯣 組織間質にある細胞(間質細胞とよぶ)を用いて造血 幹細胞を培荃系で維持できる骨䯣機能の再構成を目 指して研究した.

造血幹細胞は赤血球，白血球，血小板などすべて の血液細胞を恒常的に産み出す多能性幹細胞である が, この恒常的造血が起こる組織は, 個体発生に伴っ て肧では卵黄簬, 胎児では肝臓, 誕生してからは骨 䯣へと移動する。このことは，個体発生に伴い，造 血幹細胞が造血に好適な環境(造血微小環境: hematopoietic microenvironment)へ移動すること によるものと考えられおり, 最近の多能性幹細胞の 再生医学研究のうえからも，これら造血組織の造血 微小環境がいかに構成されており，また制御されて いるかが重要な研究課題となってきた。なかでも骨 髄は, 造血幹細胞や血液前駆細胞の增殖分化の制御 の場として重要な組織であり，筆者らはこの骨髄の 造血微小環境がこの組織を構成する間質細胞によっ てつくり出されており，これら間質細胞が造血細胞 の増殖と分化の制御に多様な機能を持っていると推 定した。

実際, Dexter らは骨髄から取り出したシャーレに 付着性の間質細胞をフィーダーとして血液細胞を培 養すると, 長期の造血細胞の維持が in vitro 培養系 で可能であることを報告しており (Dexter's longterm bone marrow culture とよばれる)，この混合 培養系では, 造血幹細胞が増殖(自己複製)しつつ分 化し，成熟した血液細胞が長期的に産生されている ものと考えられ，シャーレに付着性の間質細胞が幹 細胞の増殖分化を支持していることを裏付けるもの である

間質細胞の支持機能には間質細胞と血液細胞直接 の接着, 細胞外基質 (extracellular matrix), さらに はサイトカインの産生などが重要と考えられている が，その具体的な分子メカニズムは明らかにされて いない. その後, 血液細胞の増殖分化の制御の研究 は, サイトカインについて集中的に行われたが，少 なくとも現在まで，これらサイトカインを組み合わ せても満足のゆく形で in vitro で幹細胞を維持でき る条件は見いだせていないことから, 間質細胞の造 血支持機能により注目が集まってきた，

そこで筆者らは，できるだけ多数の多様な骨髄間 質細胞株を樹立し，これらにより培養系で造血微小 環境を再構築しようと考え，SV40 T-抗原トランス ジェニックマウスの骨髄から接着性の細胞を培養 し, 多数 (60クローン)の間質細胞株を樹立すること に成功した ${ }^{8)}$.

樹立された間質細胞株は形態学的観察, 生化学的 解析などから, 線維芽細胞, 前脂肪細胞, 内皮細胞 の 3 種に大別されることがわかった。これらの細胞 は, Dexter's culture において付着性の細胞として 
表 1 トランスジェニックマウス, ラットから樹立された細胞株とその文献リスト

(Established cell lines from T-transgenic mice and rats）[細胞株（クローン名）(参考文献）分化マーカーの発現]

Kidney tubule cell lines

\section{MOUSE CELL LINES}

distal tubule cell line (TKC-2) $(2,5,40)$

characters of distal tubule cells, dome formation, vasopressin-induced cAMP synthesis

early proximal tubule cell line(S 1) (6),

unique morphology specific to proximal tubule

vasopressin-induced intracellular calcium increase

kidney tubule cell lines from microdissected nephron segments $(7,15)$

distal tubule, cortical and outer medullary collecting duct(OMCD), terminal proximal tubules(S 3 segment) intrarenal site-specific actions

hepatocyte cell lines(TLR) (1)

liver-specific morphological and biochemical properties inducibility of P 450 IA 1 by 3-methylcholanthrene

gastric surface mucous cells GSM 06 and GSM 10(3)

PAS-and Con A-positive glycoproteins

tracheal epithelial cell lines, TM 01 and TM 02-3(18)

high molecular weight glycoconjugates, ICAM-1

colonic epithelial cell line (MCE 301) (26)

microvilli-like structures, tight junctions and desmosomes, cytosketal(acidic cytokeratins and actin), basement membrane (laminin and collagen type IV)

junctional complex proteins( $(2 \mathrm{O}-1$ and desmoplakin I + II), alkaline phosphatase(a brush border-associated enzyme)

retinal pigment epithelium-derived cell line(RPET) (14)

T 1-tyrosinase production, cytokeratin, microvilli

vascular smooth muscle cell lines(SVS 30 and SVS 24 cells) $(17,21)$

$\alpha$-actin, smooth muscle myosin heavy chain-1, and calponin. proliferation-dependent expression

bone marrow stromal cell lines

mesencymal stem cell and progenitor cell lines

bone marrow stromal cell line(TBR 31-2) (22)

multipotency of mesenchymal cell differentiation, adipocyte(lipoprotein lipase)

osteoblast(type I collagen and osteocalcin), chondrocyte (type II and X collagen)

muscle cell (desmin)

bone marrow stromal cell line(TBR-B) (25)

differentiation potential to smooth muscle, $h 1$-calponin, $h$-caldesmon, SM22 $\alpha$ and $\alpha$-actin

bone marrow stromal cell line(TBR-series) (9)

differentiation potentials to mesenchymal lineages of cells

bone marrow stromal cell line for reconstruction of hematopoietic microenvironment

(TBR 59) (12) support $\mathrm{Lin}-\mathrm{c}-\mathrm{Kit}+\mathrm{Sca} 1+$ stem cells sorted from bone marrow

(TBR 31-1) (12) support lymphopoieisis

(TBR-series) $(8,16) \quad$ support erythropoiesis, granulopoiesis and lymphopoiesis

(TM-series) (10) support osteoclastogenesis

hematopoietic cell line

stromal cell-dependent hematopoietic stem-like cell line

(THS-119) $(19,23)$

c-Kit, Sca-1 and CD 34 low, linaege(Gr-1, TER 119,

Mac-1, CD 3, B 220)-negative, hematopoietic cell specific transcription factors

chondrocyte-like cell line(TC 6) derived from articular cartilage (13)

type II procollagen, link protein, and aggrecan

chondrocyte cell lines (MCC-2, MCC-5, MCC-35) from the costal cartilage (28)

type II, type XI, and type X-collagens, aggrecan, link protein periodontal ligament fibroblasts(PDL-L 2) (44)

alkaline phosphatase, type I collagen, periostin, runtrelated transcription factor-2(Runx 2) and EGF receptor,

epididymal cell lines(PC 1 from proximal caput; and $\mathrm{DC} 1$,

DC 2, and DC 3 from distal caput) (42)

expression of cytokeratin, epididymal specific proteins (androgen receptor, PEB-like protein, E-RABP, and EP 17)

testicular Sertoli cell line(TTE 3) (37)

Sertoli cell-specific genes (steel factor, inhibin- $\alpha$, transferrin, follicle-stimulating hormone receptor and sulfated glycoprotein-2)

vimentin and zonula occludens- 1 , mRNAs for $17 \beta$-HSD types 1 and 3 , and inhibin- $\alpha$

Leydig cell Line, (TTE 1) (36)

alkaline phosphatase and $3 \beta$-hydroxysteroid dehy. drogenase (HSD) activities

expression of cytokeratin and vimentin

adrenocortical precursor cell lines(AcA 201, AcE 60 and AcA 101) (35)

steroidogenic genes encoding steroidogenic factor-1, cholesterol side-chain cleavage P $450 \mathrm{scc}$, and steroidogenic acute regulatory protein,

gingival epithelial cell lines (GE 1 and GE 6) (31)

Characteristic keratin peptides, keratin 4 and 13, for mucosal epithelium

Filaggrin, involucrin, IL- $1 \beta$ and TNF- $\alpha$ by the stimulation of lipopolysaccharide

\section{RAT CELL LINES}

bone marrow-derived endothelial cell lines(TR-BME) (32)

(VEGF) receptor(VEGFR)-1, 2, Tie-1, 2 and von Willebrand factor(VWF)

choroid plexus epithelial cell line (TR-CSFB) (30)

transthyretin, $\mathrm{Na}+, \mathrm{K}+-\mathrm{ATP}$ ase uptake of L-Proline or L-glutamic acid

brain capillary endothelial cell lines(27)

von Willebrand factor, acetylated low-density lipoprotein uptake activity,

tight-junction strand proteins(claudine-5, occludin), junctional adhesion molecule

drug efflux transporter ( $\mathrm{P}$-glycoprotein, $\mathrm{mdr} 1 \mathrm{a}, \mathrm{mdr} \mathrm{1b}$, and mdr 2)

drug influx transporter(GLUT-1, 3-O-methyl-D-glucose (3-OMG) uptake activity)

large neutral amino acid transporter

retinal capillary endothelial cell lines(TR-iBRB) (29)

von Willebrand factor, acetylated-low density lipoprotein uptake activity

VEGF receptor-2, GLUT 1 , mdr $1 \mathrm{a}$, mdr $1 \mathrm{~b}$ and mdr 2

syncytiotrophoblast cell lines, (TR-TBTs) (43)

Polarized glucose transporters

betaine/GABA transporter (GAT-2/BGT-1), concentrative nucleoside transporter 2(CNT 2), equilibrative nucleoside transporter 1(ENT 1), and ENT 2 gastric epithelial cell lines(RGE 1-01, RGE 1-02, RGE 1-03,

RGE 1-21, RGE 1-22 and RGE 2-01) (39)

cytoskeletal (cytokeratin and actin), basement membrane (laminin and collagen type IV)

junctional complex (ZO-1 and desmoplakin I + II) proteins

brain pericyte cell lines, TR-PCT 1(38)

responds to transforming growth factor $\beta 1$ and $\beta$-glycerophosphate

type 2 astrocyte cell line(TR-AST) (33)

GFAP and A 2 B 5 glutamine synthetase. acidic amino acid transporters, GLT-1

bone marrow-derived endothelial cell lines(TR-BME) (32)

VEGFR-2, VEGFR-1, Tie-1, 2, and VWF 
報告されているものとよく一致していた．

\section{1. 骨髄間質細胞株の造血前駆細胞の特異的支持機能}

筆者らは，樹立した骨髄間質細胞を用いて造血微 小環境を in vitro で再構成し, 幹細胞や前駆細胞の 培養を行うことが造血幹細胞の増殖と分化の遺伝子 制御を研究するために重要と考え, 間質細胞株を フィーダーとして, 造血細胞を共培養する新たな培 養系を開発し，まず，血液前駆細胞に対するこれら 間質細胞株の造血支持機能を系統的に調へたた，骨髄 または胎仔肝の前駆細胞をこれら間質細胞株を フィーダーとして培養すると, 支持機能がある場合 は巨大なコロニー(数百個〜千個の細胞からなる)が 形成される.この巨大コロニーの細胞を観察すると, 赤血球系コロニー, 顆粒球コロニーなどが認められ, 間質細胞株の種類により, エリスロポイエチン依存 に赤血球造血支持機能を持つものや, 顆粒球造血支 持機能を持つものなど，その造血支持機能に選択性 があることがわかった。

赤血球造血の支持機能は, エリスロポイエチンの 添加が必須であったが，顆粒球やマクロファージ系 のコロニー形成を支持する細胞は, G-CSF, M-CSF などのサイトカインの産生とは無関係に支持し, こ れらサイトカインを添加しても支持機能の六進は認 められない.

この赤芽球と間質細胞の共培養系を用いて予想さ れる既知分子について阻害抗体を用いた実験を行 い, 間質細胞の赤血球造血支持には c-Kit や VLA4 が必須であることがわかった. c-Kitのリガンド である stem cell factor(SCF) は, 間質細胞で発現し ており, 膜結合型と分泌型のフォームが存在する. 両者ともに血液細胞に発現する $c-K i t$ 受容体を介 して未分化血球細胞の増殖を制御している、VLA-4 は, 細胞外基質である VCAM-1 と結合することで 細胞の生存や接着シグナルを調節していると考えら れている.

これらの結果から間質細胞の造血支持機能は, 血 球との細胞間の直接の相互作用を介した制御である ことがわかり, 今後, こうした細胞間相互作用を介 して働く新しい機能分子の同定にこれら間質細胞株 は有用な材料として利用できるであろう.

\section{2. 骨髄間質細胞株による造血幹細胞の增殖分化誘導}

骨髄では造血幹細胞の増殖分化を制御すると予想 されるので，骨髄間質細胞株を用いて造血幹細胞の 長期維持培養が可能かどうか調ベた。 セルソーター を用いて, 造血幹細胞 (血球分化マーカー(Lineage) 陰性, c-Kit 陽性, Sca-1 陽性)を純化し, これをさ まざまな骨髄間質細胞株と共培養したところ, 造血 幹細胞は間質細胞の下に潜り込んで増殖し, 分化す るにつれて間質細胞依存性が低下し, 間質細胞の表 層側に浮き上がってくる傾向がみられ，増殖した細 胞はいわゆる敷石状のコロニー (cobblestone コロ ニー)を形成する.このコロニー形成能を指標に, 各 問質細胞の造血支持機能を比較すると, 強い支持機 能を示すものから，まったく支持しない細胞株まで 存在することがわかり, 骨髄間質細胞は, 造血幹細 胞の分化方向の決定や前駆細胞の増幅に対して多様 な能力を示すことがわかった ${ }^{12)}$ ，この造血幹細胞の 間質細胞による支持機能においても，阻害抗体を用 いた奏験により c-Kitや VLA 4 が重要であること が証明された。

こうして，樹立した間質細胞株と分画した造血幹 細胞の共培養系として, in vitroで造血微小環境を 再構築することが可能となってきた．

つぎに，造血幹細胞はセルソーターで純化できる ものの, ソーティングされた細胞は, その後の解析 に十分な細胞数を得られないことから, 造血幹細胞 が不死化されれば，間質細胞との相互作用を分子レ ベルで解明する有用な材料となるのではないかと考 え, 株化された間質細胞依存的に増殖する造血幹細 胞株の樹立を試みた. ts-T-antigen トランスジェ ニックマウスの骨髄由来の Lineage-Sca-1+細胞 を, 造血支持能の高い間質細胞株 TBR 59 を支持細 胞と培養し，長期にわたって継代すると，ソーティ ングした造血幹細胞と同様に間質細胞の下に潜り込 んで cobblestone コロニーを形成して増殖し,また, 細胞表面マーカーの Lineage-c-Kit + Sca-1+と いった発現パターンやその転写因子などの発現から も, 幼若な血球細胞の特性を持つ未分化血球細胞株 THS 119 を樹立することに成功した ${ }^{19)}$. THS 119 細胞の増殖は間質細胞依存的であり, 間質細胞を除 くと apoptosis を起こし死隇する. また, TBR 59 間 
質細胞株以外の細胞株ではその増殖を維持できない 間質細胞株があり,このような間質細胞株に TBR 59 間質細胞の conditioned medium を加える と増殖を回復することから，その維持には接着性の 因子と液性因子の関与が考えられた. THS 119 細胞 は，間質細胞がない状態では各種サイトカインのみ で維持することはできなかったが，THS 119 と TBR 59 の共培養下に 2 力月にわたり各種サイトカ インを添加しつづけたところ, IL-3 あるいは IL-7 に依存し增殖する THS 119 の亜株が得られた。こ れら THS 119 細胞を用いて, 間質細胞依存的な増 殖とサイトカイン依存的な増殖の相違を調べた。そ の結果, サイトカイン依存的な THS 119 は恒常的 にSTAT 5 のリン酸化が認められるのに対し, 間質 細胞依存的な THS 119 細胞ではSTAT 5 のリン酸 化が非常に弱いことがわかった．末分化な幹細胞は 間質細胞の助けをかりて未分化性を維持されている が，いったん分化が誘導されると，間質細胞依存性 を失い，サイトカイン依存性を獲得し，その後の分 化成熟経路に進むと考えられるので, 間質細胞依存 性 THS 119 細胞株と, サイトカイン依存性の覀株 との比較により, 間質細胞依存性からサイトカイン 依存性への転換の機構や，それそれれの増殖促進シグ ナルの違いなどを解析するよい材料となると思われ る.

THS 119 細胞も間質細胞の下に潜り込んで cobblestone コロニーを形成して増殖することか ら，末分化血球細胞が間質細胞へ潜り込むという性 質を保持していたので, この細胞系でこの潜り込み がどのような因子によるのか解析したところ, 興味 深いことに THS 119 細胞の潜り込みには血清中の 脂質成分である sphingosine-1 phosphate(S 1 P) と lysophosphatidic $\operatorname{acid}(\mathrm{LPA})$ が関与しているこ とが明らかとなった ${ }^{24)}$. S 1 P P LPA は, 造血細胞 の膜受容体である edg-1, あるいは edg-2 を介し， また，阻害風の実験から低分子 $\mathrm{G}$ 蛋白を介するシグ ナルにより末分化血球細胞の運動能を制御している ことが証明された，実際，分画した造血幹細胞でも edg-1, edg-2 が発現していることを確認しており， 脂質が未分化な造血細胞の重要な生理的因子として 働く可能性があり興味深い結果である.
さらに，正常マウス骨髄細胞を Dexter 型の支持 細胞の上で長期継代したのち, 間質細胞依存的に維 持される血液細胞のみを既存の間質細胞株 MSS 62 へ移し換え, MSS 62 細胞株依存に維持される共培 養系 DFC を樹立した ${ }^{41)}$. この DFC 細胞の培養から いくつかの未分化造血細胞株を樹立したが，そのな かで DFC-28 細胞は, MSS 62 に依存的に未分化状 態が維持される造血前駆細胞株であり, フィーダー 細胞を MSS 62 から別の骨䯣間質細胞株 TBR 31-1 との共培養へ移すと, c-Kitの発現低下, および $\mathrm{Pax}^{-5}$ の発現上昇を伴って初期 B リンパ球へ分化 誘導されることがわかった。この分化誘導は, リン パ球系サイトカインである IL-7 や TBR 31-1 の培 養上清の添加では起こらず, TBR 31-1 との直接的 な接着を介したシグナルが必要であることが示唆さ れた.また, 驚くべきことに, いったん TBR 31-1 と 共培養した DFC-28 細胞を再びMSS 62 と共培養 すると，もとの未分化な形質に戻った。これは間質 細胞との直接的なシグナルが，未分化血球細胞の可 逆的な分化のスイッチに関与している可能性を示唆 するものである. $\mathrm{Pax}^{-5}$ は B リンパ球の分化決定に 重要な転写因子の一つであるが, Pax -5 を欠損する proB 細胞は, 特定の条件下で他の血球系列(顆粒 球, マクロファージ, T リンパ球, NK 細胞, 破骨 細胞等)へ分化できることが報告されているので, Pax-5の発現が起こる前の細胞は分化の可塑性を 有していると考えられ，DFC-28でみられた間質細 胞による Pax-5 の可逆的な発現は, B リンパ球への 分化決定のみならず未分化血球の分化の可塑性を研 究するうえで興味深い。この結果は，未分化な幹細 胞が末分化状態と分化状態を可逆的に変換できるこ と, そしてこの可逆性が間質細胞など外的因子によ り制御を受けていることを示唆するものであり，再 生医学研究のうえから, いかに幹細胞の可塑性を制 御し，ある方向への分化誘導を可能にするかという 点で微小環境を構成する間質細胞の重要性が増して きたといえる。

\section{3．間葉系幹細胞としての骨髄間質細胞の性質}

樹立された骨䯣間質細胞株は，造血に対しては多 様な支持能を示すが，同時にそれ自身は前脂肪細胞 


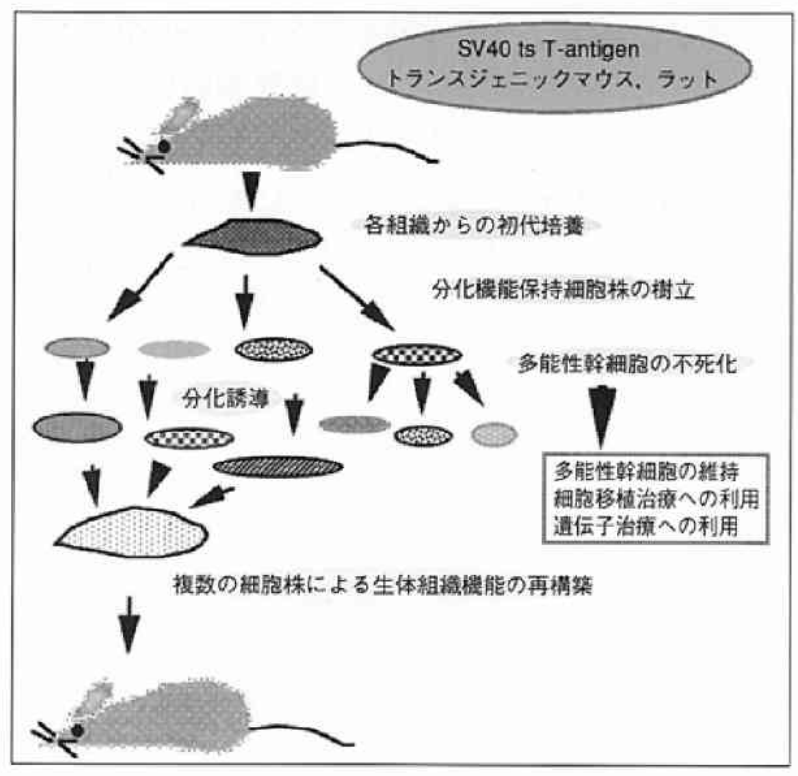

図 2 分化機能保持細胞株の樹立とこれを用いた生体組織 機能の再㮖築

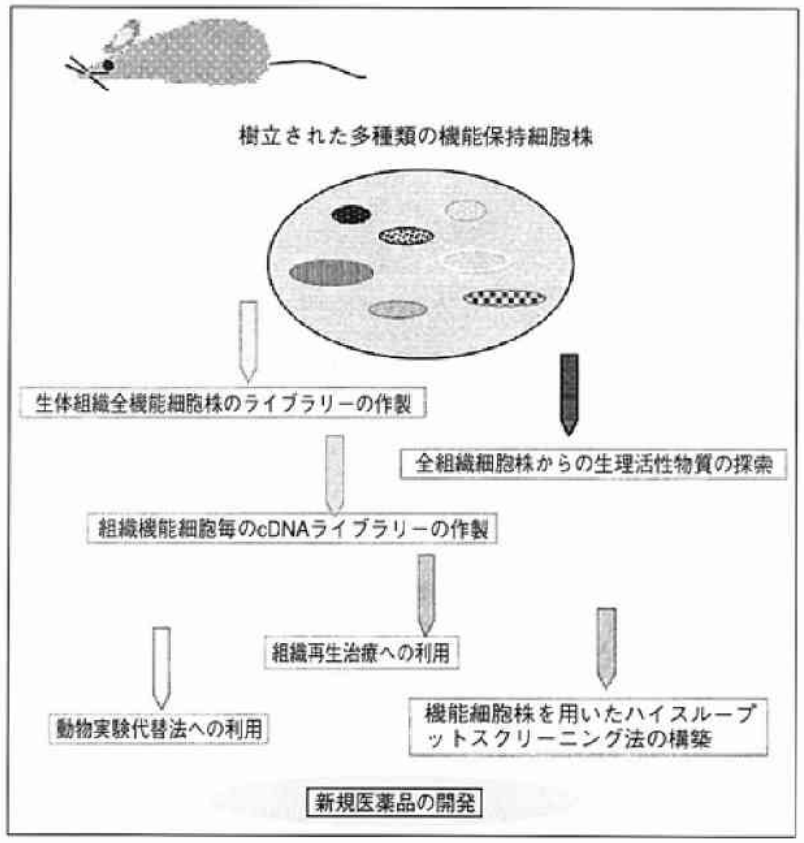

図 3 分化機能保持紐胞株の医薬品開発人の利用

や血管内皮細胞, あるいは骨芽細胞, 筋芽細胞といっ た間葉系幹細胞の性質を有していることがわかっ た。これら間質細胞株は，ある培養条件下では成熟 した脂肪細胞, 骨細胞, 筋肉へと分化が可能であり, なかには一つの間質細胞が脂肪細胞, 骨細胞, 筋細 胞へと分化できる多能性細胞もあることを示した． また, 最近筆者らは, 間質細胞から心筋細胞へと分
化誘導が起きることを示す結果も得ている．最近の 再生医学研究では, 骨䯣の細胞を移植すると, 肝臟, 心臓，神経など多様な組織細胞への分化能を示すと いう報告がなされ，その実体に注目が集まっている．

また, 骨髄の造血微小環境を構成する間質細胞が, このように間質細胞が間葉系幹細胞としての分化転 換能を持っていることは, 骨髄の造血微小環境を構 築してゆくためにどのような制御を受けているかと いう点からも興味が持たれる、筆者らは, 造血組織, 特に骨䯣で血液細胞が産生している Oncostatin M (OSM) に注目して, OSM の間質細胞に対する効果 を検討したが，ある間質細胞株では，骨芽細胞や脂 肪細胞へと分化誘導される際に, OSM が抑制する 一方で, 造血促進因子である SCF の産生を上昇さ せる働きがあることがわかった ${ }^{34)}$.この結果は, 血液 細胞が産生する因子により間質細胞の増殖や分化が 制御されることを示しており，骨髄では血液細胞と 間質細胞の間で双方向シグナルによる制御により造 血微小環境を維持しているという新しい組織制御系 があることを示すものとして興味深い.

\section{まとめ}

不死化遺伝子導入トランスジェニックマウスは, いろいろな組織の機能細胞株の樹立にきわめて有効 であり，ここで述へてきたように，これら樹立され た複数の細胞株を組み合わせて培養することにより 培養系で組織機能の再構成を進めてゆけば, 組織形 成の機構や複合的な組織機能の再構成の研究も可能 になり, 将来的には遺伝子治療, 幹細胞移植, さら には組織再生など, 疾患の新しい治療法のための基 礎研究にも応用できるものと期待している(図 2).

また，すでに樹立された腎尿細管細胞，胃粘膜細 胞, 平滑筋細胞などは, 薬理学, 毒性研究などに利 用されはじめているし, 医薬品開発のための生体機 能を反映したスクリーニング系として，また，動物 実験代替法への利用にも期待が持てる(図 3).

\section{文 献}

1) Yanai $Y$, Suzuki $M$, Obinata $M:$ Hepatocyte cell lines established from transgenic mice harboring temperature- 
sensitive Simian Virus 40 large T-antigen gene. Exp Cell Res $197: 50-56,1991$.

2) Yanai $Y$, Satoh T, Kyo S, Abe, K, Suzuki M, Obinata M : A tubule cell line established from transgenic mice harboring temperature-sensitive Simian Virus 40 large $\mathrm{T}$ antigen gene. Jpn J Cancer Res 82 : 1344-1348, 1991.

3) Sugiyama N, Tabuchi $Y$, Horiuchi T, Obinata M, Furusawa $\mathrm{M}$ : Establishment of gastric surface mucous cell lines from transgenic mice harboring temperature-sensitive Simian Virus 40 large T-antigen gene. Exp Cell Res $209: 382-387,1993$.

4) Yanai $Y$, Obinata $M$ : Apoptosis is induced at nonpermissive temperature by a transient increase in p 53 in cell lines immortalized with ts SV40 T-antigen gene. Exp Cell Res 211:296-300, 1994.

5) Takeuchi K, Yanai N, Takahashi N, Abe T, Tsutsumi E, Obinata $\mathrm{M}$ et al. : Different cellular actions of vasopression-induced adenosine 3', 5'-monophosphate formation in an immortalized renal tubule cell line, TKC 2 . Biochem Biophys Res Commn 202: 680-687, 1994.

6) Sekine T, Hosoyamada M, Haga-Mizuno A, Takeda M, Suzuki M, Obinata M et al. : Ammonia production in cell lines established from transgenic mice harboring temperature-sensitive simian virus 40 large $\mathrm{T}$-antigen gene. Contrib Nephrol $110: 98-102,1994$.

7) Takeda M, Hosoyamada M, Shirato I, Obinata M, Suzuki $M$ et al. : Establishment of vasopressin-responsive early proximal tubular cell lines derived from transgenic mice harboring temperature-sensitive simian virus 40 large $T$ antigen gene. Biochem Mol Biol Int 37:507-515, 1995.

8) Kameoka JI, Yanai N, Obinata M : Bone marrow stromal cells selectively stimulate the rapid expansion of lineagerestricted myeloid progenitors. J Cell Physiol $164: 55-$ 64,1995

9) Okuyama R, Yanai N, Obinata M : Differentiation capacity towards mesenchymal cell lineages of bone marrow stromal cells established from temperature-sensitive SV40 T-antigen transgenic mouse. Exp Cell Res 218: 424-429, 1995

10) Matsumoto NH, Tamura M, Denhardt DT, Obinata M, Noda M : Establishment and characterization of bone marrow stromal cell lines that support osteoclastgenesis. Endocrinol 136: 4084-4091, 1995.

11) Taher A, Yanai N, Obinata $M:$ Properties of incompletely immortalized cell lines generated from the line established from temperature-sensitive SV40 T-antigen transgenic mice. Exp Cell Res $219: 332-338,1995$.

12) Okuyama R, Koguma M, Yanai N, Obinata M : Bone marrow stromal cells induce myeloid and lymphoid development of the sorted hematopoietic stem cells in vitro. Blood 86:2590-2597, 1995.

13) Mataga N, Tamura M, Yanai N, Shimomura T, Kimata $\mathrm{K}$, Obinata $\mathrm{M}$ et al. : Establishment of a novel chondrocyte-like cell line derived from transgenic mice harboring temperature sensitive Simian Virus 40 large Tantigen gene. J Bone and Mineral Res 11:1646-1654, 1996.

14) Kato $K$, Ishiguro $S$, Yamamoto $H$, Yanai $N$, Obinata $M$ et al. : A retinal pigment epithelium-derived cell line from transgenic mouse harboring temperature-sensitive Simian Virus 40 Large T-antigen gene. Cell Struct \& Funct 21 : 459-468, 1996.

15) Hosoyamada M, Obinata $M$, Endou $H$ : Cisplatin-induced toxicity in immortalized renal cell lines established from transgenic mice harboring temperature sensitive SV40 large T-antigen gene. Arch Toxicol 70:284-292, 1996.
16) Iguchi A, Okuyama R, Koguma M, Yanai N, Obinata M : Bone marrow stromal cells induce granulocytic development in the absence of G-CSF. Cell Struct \& Funct 22 : 357-364, 1997.

17) Hasegawa K, Arakawa E, Oda S, Yanai N, Obinata M et al. : Novel smooth muscle cell lines from transgenic mice harboring temperature-sensitive SV40 large T-antigen gene. temperature-dependent expression of smooth muscle myosin heavy chain-1 and calponin genes. J Mol Cell Cardiol 29:2177-2186, 1997

18) Sugiyama $N$, Tabuchi $Y$, Numata $F$, Horiuchi $T$, Ishibashi $\mathrm{K}$ et al. : Establishment and characterization of tracheal epithelial cell lines, TM 01 and TM 02-3, from transgenic mice bearing temperature-sensitive SV40 large Tantigen gene. Cell Structure \& Function 23:119-127, 1998.

19) Yanai N, Matsui N, Matsuda KI, Furusawa $T$, Ohkubo $T$ et al. : A novel stromal cell-dependent hematopoietic cell line established from temperature-sensitive SV40 Tantigen transgenic mice. Exp Hematol 27:1087-1096, 1999.

20) Takahashi R, Hirabayashi M, Yanai N, Obinata M, Ueda $\mathrm{M}$ : Establsihment of the tsA 58 transgenic rats as a source of conditionally immortalized cell lines. Experimental Animals 48:255-261, 1999.

21) Sugiyama $T$, Hasegawa $K$, Yanai $N$, Mikoshiba $K$, Obinata $\mathrm{M}$ et al. : Alteration of the increase in intracell ular $[\mathrm{Ca}(2+)]$ in proliferating smooth muscle cells. Biochem Biophys Res Commun 264: 774-776, 1999.

22) Negishi $Y$, Kudo A, Obinata A, Kawashima K, Hirano $H$ et al. : Multipotency of a bone marrow stromal cell line, TBR 31-2, established from ts SV $40 \mathrm{~T}$ antigen gene transgenic mice. Biophys Biochem Res Commn 268: 450-455, 2000.

23) Okubo T, Yanai N, Obinata M : Self-renewal and differentiation of a novel bipotent myeloid progenitor cells in the stroma-dependent culture. Exp Hematol 28:651659, 2000.

24) Yanai N, Matsui N, Furusawa T, Okubo T, Obinata M : Sphingosine-1-phosphate and lysophosphatidic acid trig ger invasion of primitive hematopoietic cells into stromal cell layers. Blood 96:139-144, 2000.

25) Arakawa E, Hasegawa K, Yanai N, Obinata M, Matsuda $\mathrm{Y}$ : A mouse bone marrow stromal cell line, TBR-B, shows inducible expression of smooth muscle-specific genes. FEBSLetters 481: 193-196, 2000.

26) Tabuchi $Y$, Ohta S, Arai Y, Kawahara M, Ishibashi K et al. : Establishment and characterization of a colonic epithelial cell line MCE 301 from transgenic mice harboring temperature-sensitive simian virus 40 large $\mathrm{T}$-antigen gene. Cell Struct Funct $25: 297-307,2000$.

27) Hosoya K, Takashima T, Tetsuka K, Nagura T, Ohtsuki $\mathrm{S}$ et al. : mRNA expression and transport characterization of conditionally immortalized rat brain capillary endothelial cell lines: a new in vitro bbb model for drug targeting. J Drug Target $8: 357-370,2000$.

28) Kitaoka E, Satomura K, Hayashi E, Yamanouchi K, Tobiume S et al. : Establishment and characterization of chondrocyte cell lines from the costal cartilage of SV40 large $\mathrm{T}$ antigen transgenic mice. J Cell Biochem 81 : 571-582, 2001.

29) Hosoya K, Tomi M, Ohtsuki S, Takanaga H, Ueda M et al. : Conditionally immortalized retinal capillary endothelial cell lines (TR-iBRB) expressing differentiated endothelial cell functions derived from a transgenic rat. Exp Eye Res $72: 163-172,2001$. 
30) Kitazawa T, Hosoya K, Watanabe M, Takashima T, Ohtsuki S et al.: Characterization of the amino acid transport of new immortalized choroid plexus epithelial cell lines : a novel in vitro system for investigating transport functions at the blood-cerebrospinal fluid barrier. Pharm Res 18:16-22, 2001.

31) Hatakeyama S, Ohara-Nemoto $Y$, Yanai N, Obinata M Hayashi S et al. : Establishment of gingival epithelial cell lines from transgenic mice harboring temperature sensitive simian virus 40 large $\mathrm{T}$-antigen gene. J Oral Pathol Med $30: 296-304,2001$.

32) Hattori K, Muta M, Toi M, Iizasa H, Shinsei M et al. : Establishment of bone marrow-derived endothelial cell lines from ts-SV40 T-antigen gene transgenic rats. Pharm Res 18:9-15, 2001.

33) Tetsuka K, Hosoya KI, Ohtsuki S, Takanaga H, Yanai N, Ueda $\mathrm{M}$ et al. : Acidic amino acid transport characteristics of a newly developed conditionally immortalized rat type 2 astrocyte cell line (TR-AST). Cell Struct Funct 26:197-203, 2001.

34) Yanai $N$, Obinata $M$ : Oncostatin $M$ regulates mesenchymal cell differentiation and enhances hematopoietic supportive activity of bone marrow stromal cell lines. In Vitro Cellular \& Developmental Biology 37:698-704, 2001.

35) Mukai K, Nagasawa H, Agake-Suzuki R, Mitani F, Yanai $\mathrm{N}$ et al. : Adrenocortical precursor cell lines im. mortalized with a temperature-sensitive oncogene. Eur J Biochem 269:69-81, 2002.

36) Ohta S, Tabuchi Y, Yanai N, Asano S, Fuse H, Obinata M : Establishment of A Leydig Cell Line, TTE 1, from Transgenic Mice Harboring Temperature-Sensitive Sim. ian Virus 40 Large T-Antigen Gene. Arch Androl 348 : 43-51, 2002.

37) Tabuchi $Y$, Ohta S, Kondo T, Yanai N, Obinata M et al. : Development of a conditionally immortalized testicular Sertoli cell line TTE 3 expressing sertoli cell-specific genes from mice transgenic for temperature-sensitive simian virus 40 large $\mathrm{t}$-antigen gene. J Urol 167 : 1538$1545,2002$.

38) Asashima T, Iizuka H, Terasaki T, Hosoya KI, Tetsuka $\mathrm{K}$ et al. : Newly developed rat brain pericyte cell lines, TR-PCT 1, responds to transforming growth factor-beta1 and beta-glycerophosphate. Eur J Cell Biol 81 : 145-152, 2002.

39) Tabuchi Y, Arai Y, Ohta S, Shioya H, Takahashi R et al. : Development and characterization of conditionally immortalized gastric epithelial cell lines from transgenic rats harboring temperature-sensitive simian virus 40 large T-antigen gene. Cell Struct Funct $27: 71-79,2002$.

40) Takeuchi K, Sakurada K, Endou H, Obinata M, Quinlan MP : Differential effects of DNA tumor virus genes on the expression profiles, differentiation, and morphogenetic reprogramming potential of epithelial cells. Virology $300: 8-19,2002$.

41) Okubo T, Yanai N, Ikawa S, Obinata M: Reversible switching of expression of c-kit and Pax -5 in immature hematopoietic progenitor cells by stromal cells. Exp Hematol 30:1193-1201, 2002.

42) Araki Y, Suzuki K, Matusik RJ, Obinata M, OrgebinCrist MC : Immortalized epididymal cell lines from trans. genic mice overexpressing temperature-sensitive Simian Virus 40 large $\mathrm{T}$-antigen gene. J Androl 23:854-869, 2002.

43) Kitano T, lizasa $H$, Terasaki $T$, Asashima $T$, Matsunaga $\mathrm{N}$ et al. : Polarized glucose transporters and mRNA expression properties in newly developed rat syncytiotrophoblast cell lines, TR-TBTs. J Cell Physiol 193 : 208$218,2002$.

44) Saito $Y$, Yoshizawa T, Takizawa F, Ikegame M, Ishibashi $\mathrm{O}$ et al. : A cell line with characteristics of the periodontal ligament fibroblasts is negatively regulated for mineralization and Runx 2/Cbfa 1/Osf 2 activity, part of which can be overcome by bone morphogenetic protein- 2 . J Cell Sci 115: 4191-4200, 2002.

文献として本方法で樹立された細胞株についての発表論 文をまとめており，表1の（）の数字がこの文献番号に対 応している。これらの研究成果は大学から企業まての多数 の研究者との共同作業によるものであり，共同研究者に感 謝したい. 特に, トランスジェニックマウス，ラットの維 持管理供給に多大なご協力をいただいた共同研究者の第一 製薬 石橋光太郎氏, YSニューテクノロジー研究所上田 正次所長に感謝したい. 